\title{
Priming the cow for lactation by rapeseed supplementation in the dry period
}

\author{
B. M. Damgaard, ${ }^{1}$ M. R. Weisbjerg, and T. Larsen \\ Deptartment of Animal Science, Faculty of Science and Technology, Aarhus University, Blichers Allé 20, PO Box 50, DK-8830 Tjele, Denmark
}

\begin{abstract}
High-producing dairy cows experience a sudden and significant increase in energy requirements due to the onset of milk production in early lactation. They mobilize body reserves, mainly adipose tissue, resulting in an increased risk of production decline and the development of health disorders. The objective of the present study was to investigate the effects of feeding oilseeds (rapeseed) during the dry period, thereby priming dairy cows for metabolism of body fat in early lactation. Forty-three Holstein dairy cows were used, 14 were primiparous and 29 were multiparous ( $\geq 2$ nd lactation). In the dry period, 8 wk before expected calving until calving, the cows were fed either a diet with a high content of rapeseed in the total mixed ration (HF) or a standard total mixed ration with a low content of fat $(\mathrm{CON})$. During the first $5 \mathrm{wk}$ after calving, all the cows were fed a standard low fat lactation ration. The treatments were evaluated by performance and metabolic variables in blood and liver. The dry period diet had no effects on body weight and body condition score of the cows during the dry period and in early lactation. The daily yield of milk, protein, and lactose did not differ among treatments. However, the milk fat concentration was lower and the daily milk fat production tended to be lower for the cows fed the HF diet in the dry period compared with the cows fed the CON diet. The plasma content of nonesterified fatty acids, cholesterol, and phospholipids in the dry period was increased in the HF dry period diet compared with the CON diet. The lower plasma concentration of uric acid obtained prepartum for the cows fed the HF diet may indicate a lower rumen microbial protein synthesis. Postpartum, the plasma concentration of $\beta$-hydroxybutyric acid tended to be lower for the cows fed the HF dry period diet. The liver content of triglycerides was lower and the liver content of glycogen was higher in early lactation among the cows fed the HF dry period diet compared with the cows fed the CON diet. Based on liver glycogen, triglyceride content, and blood $\beta$-hydroxybutyric acid concentration, it could be argued that intake of
\end{abstract}

Received August 13, 2012.

Accepted March 6, 2013.

${ }^{1}$ Corresponding author: birthem.damgaard@agrsci.dk oilseeds during the dry period is a positive strategy for priming dairy cows for fat metabolism in the following early lactation.

Key words: cow, metabolite, hepatic fat infiltration, oilseed

\section{INTRODUCTION}

High-producing dairy cows experience massive metabolic changes during the transition period, from the dry period in late gestation to early lactation, due to a sudden and significant increase in the energy requirements for milk production (Bell, 1995). This period is critically important to health and production, as most health disorders occur during this time (Drackley, 1999). It is generally accepted that nutritional management in the dry period influences the metabolic status in the subsequent lactation period. Cows decline in feed intake and start to mobilize body reserves toward the end of the dry period (Grummer et al., 1995; Vandehaar et al., 1999). According to Friggens (2003), this mobilization of adipose tissue is a natural phenomenon among mammals around parturition. Mobilization of body lipid reserves results in an increased plasma level of NEFA.

Previously, Friggens et al. (2004) presented the hypothesis that feeding a high-fat ration in the dry period could prime the cow to adapt to body fat mobilization in the following lactation period. This strategy is based on the principle that feeding a high-fat ration in the dry period increases the circulating concentration of NEFA, thereby increasing NEFA uptake into the liver for preadaptation of hepatic long-chain FA metabolism (Grum et al., 1996; Friggens et al., 2004).

Previous studies in dairy cows indicated that supplementing dry cows with an SFA source was a positive strategy for priming dairy cows for body fat mobilization in the subsequent early lactation (Andersen et al., 2008). Dry cows supplemented with a source of highly saturated FA, in the form of vegetable fat powder, were compared with cows supplemented with a highly unsaturated FA, based on linseed, or cows fed a low-fat diet without fat supplementation. The cows supplemented with the highly saturated FA source revealed the lowest plasma NEFA concentration and the lowest liver triacylglycerol (TAG) concentration in the first 
2 wk of lactation compared with cows fed the highly unsaturated fat diet or the control diet. Conversely, unsaturated fat did not result in any positive effects in early lactation. However, it could be interesting to investigate the effect of moderately unsaturated fat fed to cows in the dry period.

Primiparous cows are still growing in the period before first parturition, and therefore have higher energy requirements before parturition than multiparous cows (Friggens et al., 2004). Consequently, the effect of feed supplements in the period before parturition may be different in primiparous and multiparous cows. The hypothesis behind the present study was that a high-fat (rapeseed) diet in the dry period could prime the dairy cow for body fat mobilization in the following lactation period. Therefore, the aim of the study was to investigate the effects of feeding rapeseed in the dry period on the metabolism of body fat in the periparturient period of dairy cows. Changes in BW, BCS, several blood variables, and liver concentrations of fat and glycogen were followed as indicators of metabolic status and adaptive changes in the periparturient period.

\section{MATERIALS AND METHODS}

\section{Cows and Housing}

The experimental procedures involving animals were evaluated and approved by the Danish Animal Experiments Inspectorate and complied with the Danish Laws concerning animal experimentation and care of experimental animals. The experiment was carried out at the Danish Cattle Research Centre (Tjele, Denmark) during 2009. A total of 43 Danish Holstein dairy cows (14 primiparous and 29 multiparous) were included in the experiment. The cows were kept in a loose-housing system with slatted floors and cubicles with mats of hard rubber material and sawdust as bedding. A free cow-traffic system was applied for access to an automatic milking system from DeLaval AB (Tumba, Sweden). Within the dairy unit, the cows were organized in 2 groups, and each group had access to 1 automatic milking unit (AMU) equipped with a device for automatic measurement of milk yield and milk sampling. Additionally, the AMU were equipped with a device for concentrate feeding and weighing of concentrate refusals at the end of each cow visit. Below each AMU, a platform scale from Danvaegt (Hinnerup, Denmark) was installed for automatic recording of cow BW. For automatic recording of mixed ration intake, the Insentec RIC system (Marknesse, the Netherlands) was used. The facilities and management procedures at the Danish Cattle Research Centre are described in detail by Bossen et al. (2009) and Bossen and Weisbjerg (2009).

\section{Experimental Design and Diets}

The experimental period covered the last 8 wk before expected calving and the first $5 \mathrm{wk}$ after calving. The cows were dried off at the start of the experimental period. At the day of drying off the cows were allocated to different treatments according to lactation number (1st and later) and expected calving date. The cows were allocated to 2 different diets: (1) a high content of rapeseed (high-fat; HF) in a TMR or (2) a normal dry cow diet without fat supplementation (control; CON). During wk 0 to 5 of lactation all the cows were fed a standard low-fat dairy ration. The diets were all TMR based on corn silage, grass-clover silage, and barley straw. The HF diet was further supplied with ground rapeseed on a DM basis as shown in Table 1, where the chemical composition of the diets is also shown.

\section{Data Collection and Analyses}

Information on TMR intake, concentrate intake, milk yield, milk composition, BW, and BCS was obtained as described by Bossen et al. (2009) and Bossen and Weisbjerg (2009). Energy-corrected milk was calculated as described by Sjaunja et al. (1991). Chemical analyses of individual feedstuffs and adjustment of feed rations during the study were carried out as described by Bossen et al. (2009). Feed free FA composition was analyzed as described by Palmquist and Jenkins (2003). One cow fed the HF diet developed displaced abomasum and ketosis postpartum and was omitted from the experiment.

\section{Sampling and Analysis of Blood}

Blood samples were collected weekly between 0900 and $1200 \mathrm{~h}$ from wk 5 before to wk 4 after calving. The blood samples were collected by venipuncture of a tail vein using vacutainer tubes containing sodium heparin (Vacutainer, Becton Dickinson Vacutainer Systems, Plymouth, UK), then stored on ice and centrifuged within $90 \mathrm{~min}$ at $2,000 \times g$ for $20 \mathrm{~min}$ at $4^{\circ} \mathrm{C}$. The plasma was collected and stored at $-20^{\circ} \mathrm{C}$ until further analysis.

Albumin, total protein, glucose, cholesterol, calcium, alkaline phosphatase, aspartate aminotransferase (AST), $\gamma$-glutamyl transferase (GGT), uric acid (UA), and plasma urea nitrogen (PUN) were analyzed according to standard colorimetric procedures (Siemens Diagnostics Clinical Methods for ADVIA 1650; Siemens Medical Solutions Diagnostics, Tarrytown, NY). $\beta$-Hydroxybutyrate was determined according to Nielsen et al. (2005). Nonesterified FA were determined using the Wako, NEFA C ACS-ACOD assay method 
Table 1. Dietary composition, chemical composition, and calculated energy content of the TMR for the dry period (control, high fat) and the lactation period

\begin{tabular}{|c|c|c|c|}
\hline \multirow[b]{2}{*}{ Item } & \multicolumn{2}{|c|}{ Dry period TMR } & \multirow{2}{*}{$\begin{array}{c}\text { Lactation } \\
\text { TMR }\end{array}$} \\
\hline & Control & High fat & \\
\hline \multicolumn{4}{|l|}{ Ingredient, $\%$ of $\mathrm{DM}$} \\
\hline Soybean, extracted & 2.0 & 3.7 & 7.6 \\
\hline Rapeseed, extracted & - & - & 4.8 \\
\hline Barley & - & - & 9.7 \\
\hline Rapeseed & - & 8.4 & - \\
\hline Grass silage & 29.8 & 32.7 & 31.0 \\
\hline Maize silage & 24.8 & 27.0 & 31.4 \\
\hline Barley straw & 25.4 & 27.2 & - \\
\hline Minerals & 0.68 & 0.70 & 0.95 \\
\hline Vitamins & 0.22 & 0.22 & - \\
\hline Feed salt & - & - & 0.49 \\
\hline Concentrate $^{1}$ & 17.2 & & $13.5^{2}$ \\
\hline \multicolumn{4}{|c|}{ Chemical composition, \% of DM } \\
\hline Crude fat & 2.7 & 6.4 & 3.5 \\
\hline $\mathrm{FA}^{3}$ & 1.9 & 5.1 & 2.6 \\
\hline $\mathrm{CP}$ & 13.6 & 13.1 & 18.6 \\
\hline Sugar & 4.2 & 4.3 & 8.2 \\
\hline Starch & 12.8 & 10.8 & 15.5 \\
\hline $\mathrm{NDF}$ & 46.7 & 47.4 & 31.2 \\
\hline $\mathrm{NE}_{\mathrm{L}}, \mathrm{MJ} / \mathrm{kg}$ of $\mathrm{DM}$ & 5.8 & 6.1 & 7.7 \\
\hline
\end{tabular}

(Wako Pure Chemical Industries, Osaka, Japan). Choline-containing phospholipids were determined by the Choline Oxidase, DAOS method (Wako Pure Chemical Industries).

All analyses were performed using an auto analyzer, ADVIA 1650 Chemistry System (Siemens Medical Solutions Diagnostics, Tarrytown, NY). The intraassay variation and interassay variation were $<5 \%$ for low and high controls for all metabolites and enzyme activities.

\section{Sampling and Analysis of Liver Tissue}

Liver biopsies were taken in wk 2 and 5 after calving. Liver biopsies $(12 \times 20$-mg biopsies $)$ were obtained through an incision on the right side of the cow at the tenth intercostal, where it crossed a line from midhumerus to tuber coxae. Prior to collection, a $5 \times 5$-cm area was shaved and disinfected and $10 \mathrm{~mL}$ of local anesthetic (Procasel, 2\%; Selectavet, Dr. Otto Fisher GmbH, Weyarn-Holzolling, Germany) was given. After a minimum of $10 \mathrm{~min}$, a 5 -mm incision in the skin was made. Liver biopsies were taken from this incision using a Manan Automatic Biopsy system (14 gauge $\times$ 17-mm notch; Marmon/MDTech, Gainesville, FL). The incision was closed with a disposable skin stapler $(\mathrm{Au}-$ tosuture, Roual 35W, United States Surgical, Norwalk,
$\mathrm{CT}$ ). The biopsies were immediately frozen in liquid nitrogen and stored at $-80^{\circ} \mathrm{C}$ until analyzed.

Two tubes of liver tissue (approx. $2 \times 20 \mathrm{mg}$ of wet liver tissue per tube) were prepared for lipid and glucose and glycogen extraction, respectively. Lipids were extracted according to the Folch method (Folch et al., 1957) with modifications (Bjerre-Harpøth et al., 2012). Glucose and glycogen extraction was performed according to Andersen et al. (2002). Homogenization was conducted using a tissue lyzer (Retsch TissueLyzer, Qiagen Retsch, Haan, Germany). The resulting supernatants were harvested after centrifugation at 2,000 $\times g$ for 15 min.

Analyses on liver extracts were performed using an autoanalyzer, ADVIA 1650 Chemistry System (Siemens Medical Solutions). Glucose, glycogen, and TAG were determined as previously described (Mashek et al., 2001). Choline-containing phospholipids were determined as described above for plasma.

\section{Statistical Analyses}

Blood, liver, and performance variables were subjected to ANOVA using the REML method in the mixed model procedure with multiple error terms (SAS Institute Inc., 1996). The model used included dry period diets $(\mathrm{HF}, \mathrm{CON})$, week (wk -5 to -1 in the dry period; 
Table 2. Effects of control TMR and high-fat TMR in the dry period on DMI, $\mathrm{NE}_{\mathrm{L}}$, and $\mathrm{BW}$ in wk -5 to -1 prepartum and on DMI, NE BW, BCS, milk yield, and composition of milk in wk 0 to 4 postpartum in primiparous (Primi) and multiparous (Multi) Danish Holstein cows ${ }^{1}$

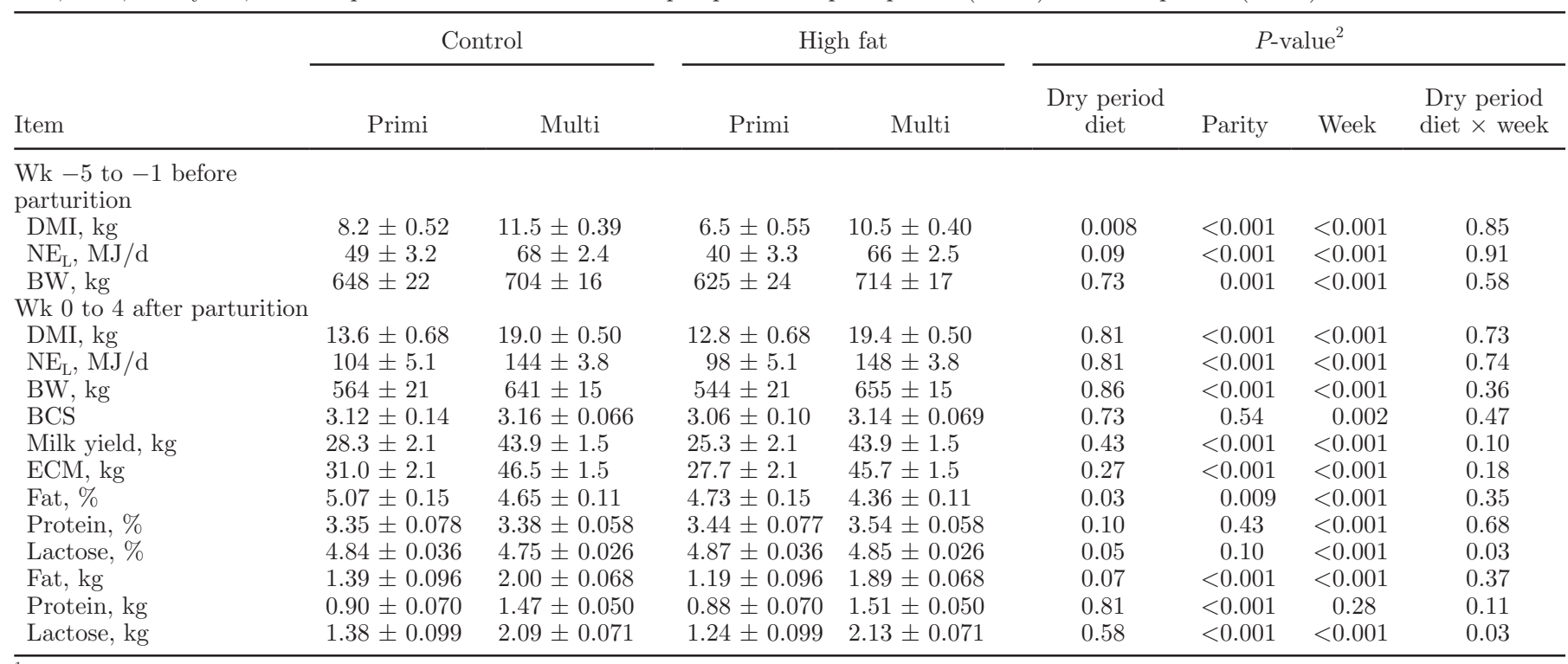

${ }^{1}$ Values are LSM and SEM.

${ }^{2}$ Interaction between the dry period diet and parity was not significant $(P>0.05)$ for all variables.

wk 0 to 4 in the lactation period), parity (primiparous, multiparous), and interactions between these fixed effects. The residual variance was assumed to be different for each feeding regimen. This was modeled using the repeated statement of PROC mixed with week as a group factor and cow as random effect (Littell et al., 2006). Degrees of freedom were estimated with the Kenward-Roger's specification in the model statement. The univariate procedure of SAS was used to determine the normality of distribution of each set of data. When necessary, natural log-transformations were performed to normalize data distribution. In addition, residuals were inspected to check that the assumptions of normal distribution and variance homogeneity were satisfactory. Results of the analysis performed by the mixed model procedure are given as LSM \pm SEM. Separation of LSM for significant effects was done using two-tailed $t$-tests using the Tukey's options in the mixed procedure of SAS. Significance is reported for $P<0.05$; tendencies are discussed at $0.05<P<0.10$.

\section{RESULTS}

\section{Milk Production, Feed Intake, and BW}

The DMI before calving was lower for both primiparous and multiparous cows fed the HF diet than for cows fed the CON diet $(P=0.008$; Table 2 and Figure 1). A tendency $(P=0.09)$ was observed to a lower energy intake for the cows fed the HF diet than for the cows fed the CON diet. The feed intake decreased for all the cows from wk 5 before calving to calving $(P<$ 0.001 ) and was considerably higher for the multiparous than for the primiparous cows $(P<0.001)$.

Body weight before calving was not influenced by the $\operatorname{diet}(P=0.73)$. Body weight was higher for multiparous than for primiparous cows $(P<0.001)$ and BW started to decrease 1 wk before calving $(P<0.001$; Table 2 and Figure 1).

Milk production, feed intake (DM and $\left.\mathrm{NE}_{\mathrm{L}}\right)$, and $\mathrm{BW}$ after calving for both the multiparous and primiparous cows were not influenced by the treatment in the dry period $(P>0.05$; Table 2 and Figure 1$)$. Milk production, feed intake, and BW were higher for the multiparous than for the primiparous cows $(P<0.001$; Table 2 ). Milk production and feed intake increased and BW decreased from parturition to $4 \mathrm{wk}$ postpartum (Table 2 and Figure 1). The concentration of milk fat was lower $(P=0.03)$ and the daily milk fat yield showed a tendency to be lower $(P=0.07)$ for the cows fed the $\mathrm{HF}$ diet than for the cows fed the CON diet (Table 2 and Figure 1). The concentration of milk protein and the daily milk protein yield were not influenced by the dry period diet. The dry period diet $x$ week interaction showed that the milk lactose concentration and the daily lactose yield were higher for cows fed the HF diet than for cows fed the CON diet $(P=0.05)$ in the first 3 wk of lactation. Daily milk fat yield decreased $(P$ $<0.001)$ and milk lactose yield increased $(P<0.001)$, whereas daily protein yield was not affected by time after calving in early lactation. Daily production of milk components was lower for the primiparous than for the 

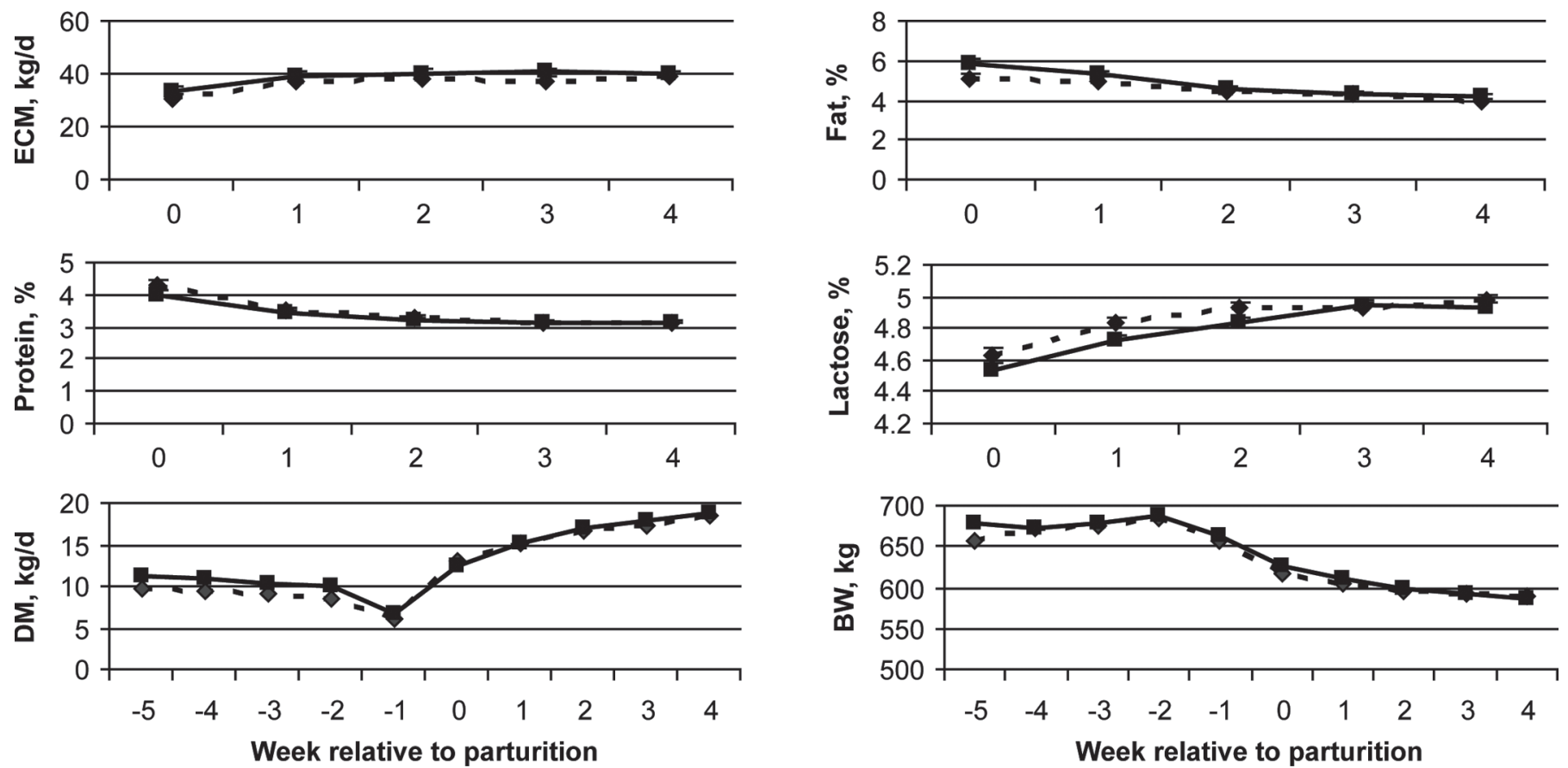

Figure 1. Changes in ECM, milk content of fat, protein, and lactose in wk 0 to 4 postpartum, and in DMI and BW from 5 wk prepartum to 4 wk postpartum in dairy cows. The cows were fed a high-fat diet (HF; dashed line) or a control diet (CON; bold line) in the dry period, and in early lactation both groups were fed the same diet. Values are LSM and SEM. See Table 2 for statistical tests.

multiparous cows $(P<0.001$; Table 2$)$. For all variables concerning milk yield, milk composition, feed intake, and BW, no significant interactions between treatment (dry period diet) and parity were found $(P>0.05)$.

\section{Plasma Metabolites}

Before calving, the plasma concentrations of NEFA, cholesterol, and phospholipids were higher, and the plasma concentrations of glucose and UA were lower for the cows fed the HF diet than for the cows fed the CON diet (Table 3 and Figure 2). Before calving, a dry period diet $\times$ week interaction showed that the plasma concentration of AST was lower for the cows fed the HF diet than for the cows fed the CON diet in wk 5 and 4 prepartum. The dry period diet $\times$ week interaction for plasma PUN showed a lower concentration of PUN for the cows fed the HF diet compared with the cows fed the CON diet in the first weeks of the dry period. After calving, the effects of the dry period diet on most variables were generally limited (Table 4 and Figure 2). The plasma concentration of GGT showed a tendency $(P=0.06)$ to be lower for the cows fed the HF diet than for the cows fed the CON diet in the dry period in early lactation. The significant interaction dry period diet $x$ week for the plasma concentrations of alkaline phosphate $(P=0.02)$, cholesterol $(P=0.02)$, and UA $(P=0.05)$ showed that the concentrations of alkaline phosphate and cholesterol were higher and the concentration of UA was lower in the first weeks after calving for the cows fed the HF diet compared with the cows fed the CON diet. The plasma concentrations of BHBA showed a tendency to be lower (0.09) for the cows fed the HF diet during the dry period than for cows fed the CON diet.

\section{Liver Metabolites}

The liver content of glycogen was higher $(P=0.008)$ and the content of TAG was lower $(P=0.006)$ in cows fed the HF diet compared with the cows fed the CON diet (Table 5). Likewise, the liver content of glycogen was higher $(P=0.001)$ and the content of TAG was lower $(P=0.001)$ for primiparous cows compared with multiparous cows. The liver content of glucose was not influenced by the dry period diet, but was higher for primiparous than for multiparous cows $(P<0.001)$. The liver content of glucose and glycogen increased $(P$ $=0.01$ and $P<0.001$, respectively), whereas the liver content of TAG decreased $(P<0.001)$ from wk 2 to 5 postpartum for all the cows. The liver content of phospholipids was not influenced by dry period diet, parity, or week after lactation $(P>0.05)$.

\section{DISCUSSION}

The cows fed the fat-supplemented dry period diet showed a decline in DMI in the dry period. However, 
Table 3. Effects of control TMR and a high-fat TMR in the dry period on plasma content of metabolites in primiparous (Primi) and multiparous (Multi) Danish Holstein cows in wk -5 to -1 prepartum $^{1}$

\begin{tabular}{|c|c|c|c|c|c|c|c|c|}
\hline \multirow[b]{2}{*}{ Item $^{2}$} & \multicolumn{2}{|c|}{ Control } & \multicolumn{2}{|c|}{ High fat } & \multicolumn{4}{|c|}{$P$-value ${ }^{3}$} \\
\hline & Primi & Multi & Primi & Multi & $\begin{array}{l}\text { Dry period } \\
\text { diet }\end{array}$ & Parity & Week & $\begin{array}{r}\text { Dry period } \\
\text { diet } \times \text { week }\end{array}$ \\
\hline Albumin, g/L & $38.0 \pm 0.46$ & $38.5 \pm 0.34$ & $37.8 \pm 0.49$ & $38.1 \pm 0.34$ & 0.36 & 0.36 & $<0.001$ & 0.42 \\
\hline Total protein, g/L & $67.8 \pm 1.3$ & $74.6 \pm 1.0$ & $68.8 \pm 1.4$ & $76.0 \pm 1.0$ & 0.34 & $<0.001$ & $<0.001$ & 0.83 \\
\hline GGT, U/L & $17.7 \pm 2.4$ & $26.8 \pm 1.8$ & $15.7 \pm 2.5$ & $23.8 \pm 1.8$ & 0.32 & $<0.001$ & 0.020 & 0.18 \\
\hline $\mathrm{AST}, \mathrm{U} / \mathrm{L}$ & $79.6 \pm 8.4$ & $80.2 \pm 6.2$ & $74.5 \pm 8.9$ & $70.6 \pm 6.4$ & 0.37 & 0.83 & 0.21 & 0.01 \\
\hline BHBA, mmol/L & $0.53 \pm 0.065$ & $0.65 \pm 0.048$ & $0.73 \pm 0.070$ & $0.57 \pm 0.049$ & 0.45 & 0.77 & 0.16 & 0.38 \\
\hline Cholesterol, mmol/L & $2.47 \pm 0.22$ & $2.92 \pm 0.16$ & $3.17 \pm 0.24$ & $3.40 \pm 0.17$ & 0.005 & 0.10 & $<0.001$ & 0.85 \\
\hline $\begin{array}{l}\text { Phospholipids, } \\
\mathrm{mmol} / \mathrm{L}\end{array}$ & $1.49 \pm 0.10$ & $1.66 \pm 0.075$ & $1.85 \pm 0.11$ & $2.00 \pm 0.077$ & 0.001 & 0.09 & $<0.001$ & 0.97 \\
\hline Glucose, $\mathrm{mmol} / \mathrm{L}$ & $3.81 \pm 0.051$ & $3.58 \pm 0.039$ & $3.68 \pm 0.054$ & $3.45 \pm 0.039$ & 0.007 & $<0.001$ & 0.22 & 0.75 \\
\hline PUN, mmol/L & $3.80 \pm 0.21$ & $4.83 \pm 0.16$ & $3.44 \pm 0.23$ & $4.43 \pm 0.16$ & 0.05 & $<0.001$ & 0.007 & 0.04 \\
\hline Uric acid, mmol/L & $24.5 \pm 1.3$ & $25.7 \pm 1.0$ & $21.5 \pm 1.4$ & $22.2 \pm 1.0$ & 0.008 & 0.44 & 0.35 & 0.26 \\
\hline
\end{tabular}

${ }^{1}$ Values are least squares means and SEM.

${ }^{2} \mathrm{GGT}=\gamma$-glutamyl transferase; AST $=$ aspartate aminotransferase; ALP $=$ alkaline phosphate; PUN $=$ plasma urea nitrogen.

${ }^{3}$ Interaction between the dry period diet and parity was not significant $(P>0.05)$ for all variables.

due to the higher energy concentration in the ration, they were almost able to maintain the same energy intake as the control cows. When limit-feeding dry cows a high-energy diet so the cows consume enough energy to meet the calculated energy requirements, Winkelman et al. (2008) found that the cows weighed less than ad libitum-fed dry cows. This difference was suggested to be due to reduced gut fill from the limited feed allowance. In the present investigation, no differences were noted in BW between the 2 groups of cows, indicating that the lower DMI in the HF group did not affect the rumen fill of the cows. Reduced DMI is common when feeding unsaturated fats and oils, which is either due to metabolic feed intake regulation or because unsaturated FA reduces the digestibility of the NDF fraction of the feed (Weisbjerg and Børsting, 1989; Pantoja et al., 1994). This probably results in low passage rates through the rumen and increased rumen filling. Unsaturated FA are toxic to protozoa and cellolytic bacteria (Jenkins, 1993), furthermore, oils have a more negative effect on the rumen environment than oilseeds and cakes (Jenkins, 1993). Moreover, oilseeds fed to ruminants instead of oils were supposed to provide a natural protection against hydrogenation of lipids in the rumen (Ekeren et al., 1992). In the present experiment, we used oilseeds in the form of rapeseed as a dietary supplement to avoid negative effects of the oil supplement.

Postpartum, no significant differences among treatments were observed for DMI, energy intake, BW, BCS, and milk yield. Similar results have been found in other experiments where cattle were fed high-fat diets during the dry period (Grum et al., 1996; Douglas et al., 2004; Andersen et al., 2008; Ballou et al., 2009). A lower milk fat percentage and a tendency for a lower milk fat yield in cows previously fed the HF diet than for the cows fed the CON diet are in agreement with the results of Grum et al. (1996). The BW and the BCS were similar for the 2 treatments, and it is therefore unlikely that the energy mobilization, and thereby the amount of FA for milk synthesis, should be different among the groups. Whether the fat intake in the dry period could indirectly affect the mammary synthesis of milk fat in the lactation period was studied by Grum et al. (1996), but remains to be elucidated further. However, other authors did not find any effects of the previous dietary fat content on the milk fat (Douglas et al., 2004; Andersen et al., 2008). The milk lactose percentage and daily milk lactose production were higher for the cows fed the HF diet than for the cows fed the CON diet in the first $3 \mathrm{wk}$ postpartum. The milk protein percentage and production were not different between the 2 groups of cows, which is in agreement with earlier results where cows were fed a fat diet during the dry period (Grum et al., 1996). The differences observed in DMI, energy intake, BW, BCS, and milk production between primiparous and multiparous cows in the present experiment are generally observed in dairy cattle.

The dietary fat content may have contributed to the increased prepartum plasma content of NEFA, cholesterol, and phospholipids in the cows fed the HF diet in the dry period. At least NEFA concentrations have formerly been observed to increase when cows were fed supplemental fat (Grummer, 1993; Grum et al., 1996). 

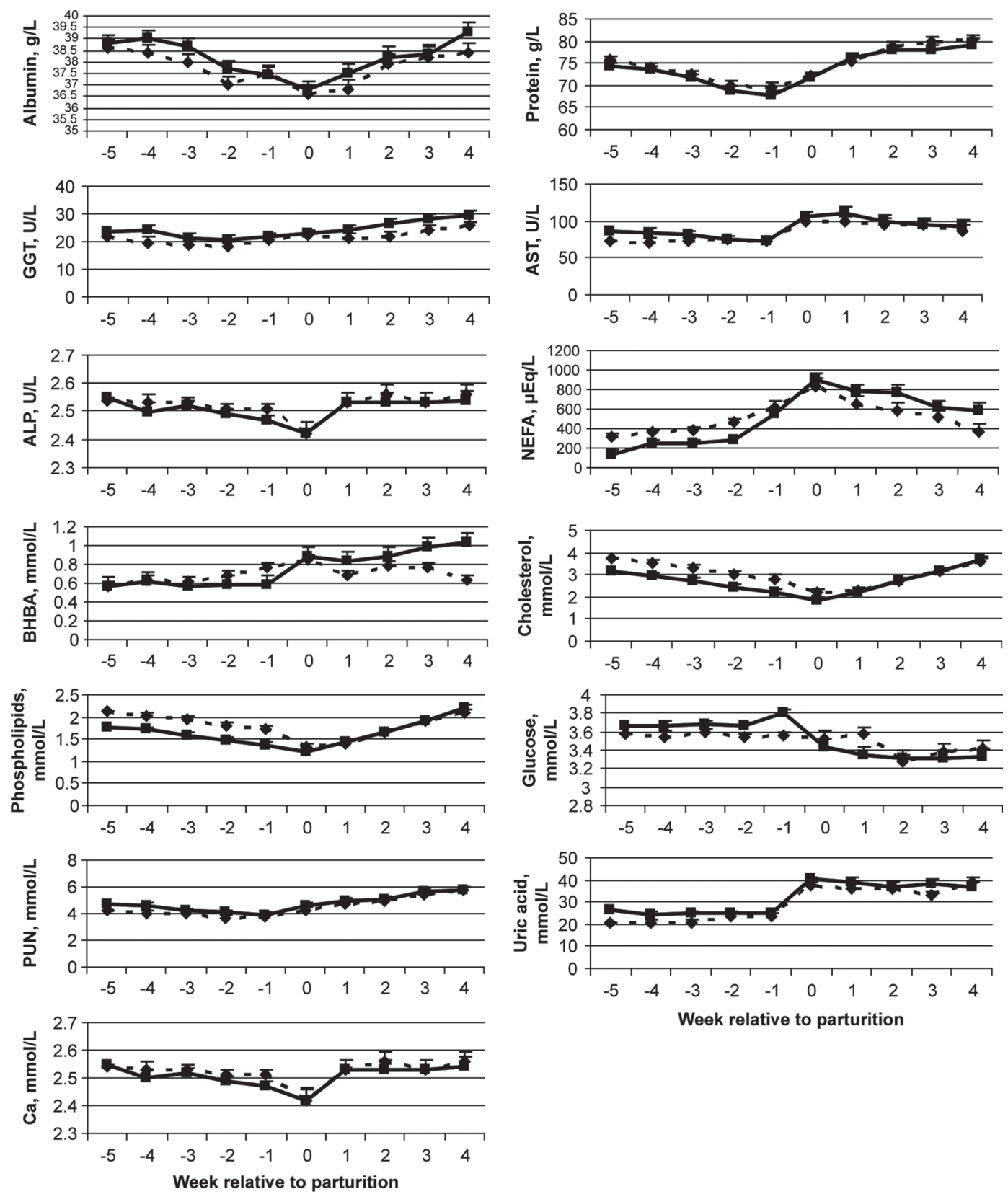

Figure 2. Changes in plasma metabolites and enzymes from 5 wk prepartum to 4 wk postpartum in dairy cows. The cows were fed a high-fat diet (HF; dashed line) or a control diet (CON; bold line) in the dry period, and in early lactation both groups were fed the same diet. Values are LSM and SEM. See Tables 3 and 4 for statistical tests. GGT $=\gamma$-glutamyl transferase; ALP $=$ alkaline phosphatase; PUN $=$ plasma urea nitrogen; AST = aspartate aminotransferase.

The lower plasma UA concentration prepartum for the cows supplemented with fat may indicate a lower rumen microbial protein synthesis (Giesecke et al., 1994) as a result of the $4 \%$ lower dietary protein content in the ration and a tendency to a lower fermentable energy intake for the cows supplemented with fat. The lower plasma PUN concentration seen in the HF group in wk 4 and 5 prepartum may be ascribed to the same factors.
The dry period diets had very limited effects on the plasma variables in early lactation. The plasma concentration of cholesterol was higher and the concentration of UA was lower in the first week postpartum for the fat-supplemented cows. This corresponds to the differences among the plasma values in the dry period, most likely because it takes some time to habituate to the new situation. Most blood variables showed a time and 
Table 4. Effects of control TMR and a high-fat TMR in the dry period on the plasma content of metabolites in primiparous (Primi) and multiparous (Multi) Danish Holstein cows in wk 0 to 4 postpartum ${ }^{1}$

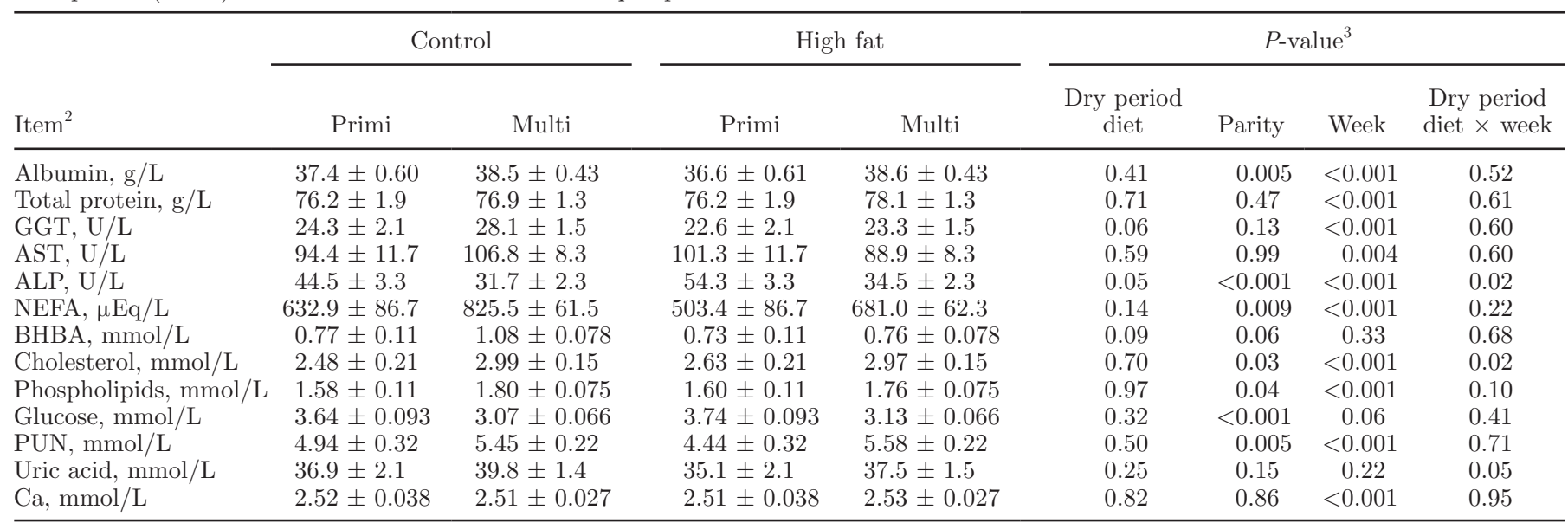

${ }^{1}$ Values are least squares means and SEM.

${ }^{2} \mathrm{GGT}=\gamma$-glutamyl transferase; AST $=$ aspartate aminotransferase; ALP $=$ alkaline phosphate; PUN $=$ plasma urea nitrogen.

${ }^{3}$ Interaction between the dry period diet and parity was not significant $(P>0.05)$ for all variables.

parity effect, which is well established for cows in the periparturient period (e.g., Andersen et al., 2005).

In the transition period, mobilization of body reserves results in an increased plasma concentration of NEFA. If the hepatic uptake of NEFA exceeds the capacity of the liver to oxidize NEFA completely, then partial oxidation may take place resulting in ketone bodies, or an esterification of FA may take place to form triglycerides. Triglycerides may subsequently be exported from the liver as very low-density lipoproteins. However, ruminants have a very limited rate of very low-density lipoprotein export from the liver, so the capacity for that route of NEFA is easily exceeded. Therefore, TAG infiltrations occur and, in severe cases, result in the development of hepatic lipidosis, a common metabolic disorder postpartum in high-producing cattle. The pathogenesis of hepatic diseases in domestic animals is remarkably complex, and several diagnostic categories have been considered (Tennant, 1997). Generally, high liver TAG content will induce higher levels of metabo- lites and enzyme activities, connected to hepatocytes, in the blood plasma due to leakage of cells. Gröhn et al. (1983) found a positive correlation between liver TAG in the cow and plasma acetoacetate, BHBA, and AST, but not GGT. Sejersen et al. (2012) compared several metabolites and enzyme activities with the actual liver TAG content in the cow. They found postpartum levels of blood NEFA, BHBA, total bilirubin, and AST to be significantly increased as a consequence of increased liver TAG, but found no significant effect on blood GGT. Similar results were obtained by Kalaitzakis et al. (2006, 2010), who grouped cows according to liver TAG content based on histological examinations of liver fat content. The situation in the present study is more complex, presumably due to the planned priming and, thereby, the dietary manipulation of the animals.

The contents of phospholipids in the liver tissue of the cows fed the HF diet and the CON diet were equal and not significantly changed from wk 2 to 5 postpartum. Sejersen et al. (2012) also found no ef-

Table 5. Effects of control TMR and a high-fat TMR in the dry period on the liver content of glucose, glycogen, triaglycerol (TAG), and phospholipids in primiparous (Primi) and multiparous (Multi) Danish Holstein cows in wk 1 and 4 postpartum ${ }^{1}$

\begin{tabular}{|c|c|c|c|c|c|c|c|c|c|}
\hline \multirow[b]{2}{*}{ Item } & \multicolumn{2}{|c|}{ Control } & \multicolumn{2}{|c|}{ High fat } & \multicolumn{2}{|c|}{ Week } & \multicolumn{3}{|c|}{$P$-value ${ }^{2}$} \\
\hline & Primi & Multi & Primi & Multi & 1 & 4 & $\begin{array}{l}\text { Dry period } \\
\text { diet }\end{array}$ & Parity & Week \\
\hline Glycogen, $\mu \mathrm{mol} / \mathrm{g}$ & $126.9 \pm 14.9$ & $86.8 \pm 10.6$ & $168.4 \pm 15.4$ & $118.6 \pm 10.6$ & $107.9 \pm 7.9$ & $142.5 \pm 8.0$ & 0.008 & 0.001 & 0.001 \\
\hline $\mathrm{TAG}, \mu \mathrm{mol} / \mathrm{g}$ & $75.4 \pm 18.4$ & $140.5 \pm 13.0$ & $33.7 \pm 18.6$ & $89.9 \pm 13.0$ & $104.2 \pm 8.5$ & $65.6 \pm 9.5$ & 0.006 & 0.001 & $<0.001$ \\
\hline Phospholipids, $\mu \mathrm{mol} / \mathrm{g}$ & $28.0 \pm 1.3$ & $27.8 \pm 0.94$ & $28.6 \pm 1.4$ & $27.1 \pm 0.94$ & $27.5 \pm 0.65$ & $28.3 \pm 0.66$ & 0.98 & 0.50 & 0.21 \\
\hline
\end{tabular}

${ }^{1}$ Values are least squares means and SEM.

${ }^{2}$ Interactions between main effects of dry period diet, parity, and week were not significant $(P>0.05)$. 
fect of liver TAG and no pronounced effect of time postpartum on phospholipids. Consequently, Sejersen et al. (2012) and the present study found an increasing positive relationship between liver TAG and liver phospholipids with increasing liver TAG content. The present material supports the view that phospholipids are mainly structural lipids, located in the hepatocyte membranes and not deposited inside cells (droplets) in notable amounts.

The main aim of the present study was to investigate if it was possible to prime the cow for fat mobilization and metabolic oxidation by feeding rapeseed in the dry period. The lower liver content of TAG and the higher liver level of glycogen in the cows fed the HF diet in the dry period support this hypothesis. This, in connection with a tendency for a lower plasma BHBA level, indicates beneficial effects on the fat metabolism postpartum. Similar observations have been obtained previously. Ballou et al. (2009) found decreased plasma BHBA and a tendency for increased plasma glucose and decreased plasma NEFA in early lactation by supplementing the diet with lipids 3 wk prepartum. However, Ballou et al. (2009) found no effect of the fat-supplemented diets on the total content of TAG in the liver. The dry period diet had no effect on the BW and BCS and, therefore, most likely had no effect on the mobilization of fat tissue and the formation of FA. The mechanism behind decreased lipids in the liver in the cows fed the HF diet during the dry period could possibly include increased $\beta$-oxidation of NEFA in the liver, decreased hepatic esterification of NEFA, or increased export of TAG from the liver. The liver content of TAG decreased and the liver content of glucose and glycogen increased significantly for both feeding groups from wk 2 to 5 postpartum. This is in agreement with earlier investigations (Grum et al., 1996; Andersen et al., 2008) and may be seen as the liver's ability to regenerate (a restoration of liver function) after fat infiltration as a result of metabolic challenge. Schmitt et al. (2011) found a marked decrease in the expression of most adipogenic transcription regulators and lipogenic enzymes after parturition in control cows and in cows supplemented with saturated fat or fish oil in the periparturient period. These results most likely constitute an important mechanism for the decrease in body fat mass in early lactation (McNamara et al., 1995) and in the content of TAG in the liver observed in early lactation in the present and other studies in cows (Andersen et al., 2008, Sejersen et al., 2012).

The fact that the content of glycogen in the liver was higher in the cows fed the HF diet throughout the dry period is in mild contrast to the fact that the plasma content and the content of glucose in the liver were similar for the 2 groups of cows, but may substantiate the beneficial effect of the oilseeds supplement in the dry period on the metabolism postpartum. Grum et al. (1996) also found effects on glycogen in the liver, but not on plasma glucose postpartum in cows fed a highenergy diet in the dry period.

\section{CONCLUSIONS}

Supplementation of rapeseed during the dry period to dairy cows did not benefit the milk production in early lactation. However, the milk fat concentration decreased and the milk fat yield tended to decrease. The intake of oilseeds had no effect on the mobilization of body reserves, but indicated a positive effect on the metabolism of FA, resulting in a decreased infiltration of TAG in the liver and an increased liver content of glycogen in the following early lactation.

\section{ACKNOWLEDGMENTS}

This work has been supported by the Danish Cattle Federation (Aarhus N, Denmark) and the Faculty of Science and Technology, Aarhus University. Gratitude is extended to laboratory technicians J. B. Clausen, L. Niklassen, and L. L. G. Jeppesen (Faculty of Science and Technology, Aarhus University) for data collection and analysis of plasma and liver and the Danish Cattle Research Centre (Tjele, Denmark) for carrying out the practical work associated with the presented research.

\section{REFERENCES}

Andersen, J. B., T. G. Madsen, T. Larsen, K. L. Ingvartsen, and M. O Nielsen. 2005. The effects of dry period versus continuous lactation on metabolic status and performance in periparturient cows. J. Dairy Sci. 88:3530-3541.

Andersen, J. B., D. G. Mashek, T. Larsen, M. O. Nielsen, and K. L. Ingvartsen. 2002. Effects of hyperinsulinaemia under euglycaemic condition on liver fat metabolism in dairy cows in early and midlactation. J. Vet. Med. (A) 49:65-71.

Andersen, J. B., C. Ridder, and T. Larsen. 2008. Priming the cow for mobilization in the periparturient period: Effects of supplementing the dry cow with saturated fat or linseed. J. Dairy Sci. 91:1029-1043.

Ballou, M. A., R. C. Gomes, S. O. Juchem, and E. J. DePeters. 2009. Effects of dietary supplemental fish oil during the peripartum period on blood metabolites and hepatic fatty acid compositions and total triacylglycerol concentrations of multiparous Holstein cows. J. Dairy Sci. 92:657-669

Bell, A. W. 1995. Regulation of organic nutrient metabolism during transition from late pregnancy to early lactation. J. Anim. Sci. $73: 2804-2819$.

Bjerre-Harpøth, V., N. C. Friggens, V. M. Thorup, T. Larsen, B. M. Damgaard, K. L. Ingvartsen, and K. M. Moyes. 2012. Metabolic and production profiles of dairy cows in response to decreased nutrient density to increase physiological imbalance at different stages of lactation. J. Dairy Sci. 95:2362-2380.

Bossen, D., and M. R. Weisbjerg. 2009. Allocation of feed based on individual cow live weight changes. II: Effect on milk production. Livest. Sci. 126:273-285. 
Bossen, D., M. R. Weisbjerg, L. Munksgaard, and S. Højsgaard. 2009. Allocation of feed based on individual dairy cow live weight changes. I: Feed intake and live weight changes during lactation. Livest. Sci. $126: 252-272$.

Douglas, G. N., T. R. Overton, H. G. Bateman, and J. K. Drackley. 2004. Peripartal metabolism and production of holstein cows fed diets supplemented with fat during the dry period. J. Dairy Sci. $87: 4210-4220$.

Drackley, J. K. 1999. Biology of dairy cows during the transition period: The final frontier? J. Dairy Sci. 82:2259-2273.

Ekeren, P. A., D. R. Smith, D. K. Lunt, and S. B. Smith. 1992. Ruminal biohydrogenation of fatty acids from high-oleate sunflower seeds. J. Anim. Sci. 70:2574-2580.

Folch, J., M. Lees, and G. H. S. Stanley. 1957. A simple method for the isolation and purification of total lipides from animal tissues. J. Biol. Chem. 226:497-509.

Friggens, N. C. 2003. Body lipid reserves and the reproductive cycle: Towards a better understanding. Livest. Prod. Sci. 83:219-236.

Friggens, N. C., J. B. Andersen, T. Larsen, O. Aaes, and R. J. Dewhurst. 2004. Priming the dairy cow for lactation: A review of dry cow feeding strategies. Anim. Res. 53:453-473.

Giesecke, D., L. Ehrentreich, M. Stangassinger, and F. Ahrens. 1994. Mammary and renal excretion of purine metabolites in relation to energy intake and milk yield in dairy cows. J. Dairy Sci. 77:23762381.

Gröhn, Y., L. A. Lindberg, M. L. Bruss, and T. B. Farver. 1983. Fatty infiltration of liver in spontaneously ketotic dairy cows. J. Dairy Sci. $66: 2320-2328$.

Grum, D. E., J. K. Drackley, R. S. Younker, D. W. LaCount, and J. J. Veenhuizen. 1996. Nutrition during the dry period and hepatic lipid metabolism of periparturient dairy cows. J. Dairy Sci. 79:1850-1864.

Grummer, R. R. 1993. Etiology of lipid-related metabolic disorders in peripaturient dairy cows. J. Dairy Sci. 76:3882-3896.

Grummer, R. R., P. C. Hoffman, M. L. Luck, and S. J. Bertics. 1995. Effect of prepartum and postpartum dietary energy on growth and lactation of primiparous cows. J. Dairy Sci. 78:172-180.

Jenkins, T. C. 1993. Lipid metabolism in the rumen. J. Dairy Sci. 76:3851-3863.

Kalaitzakis, E., N. Panousis, N. Roubies, N. Giadinis, E. Kaldrymidou, M. Georgiadis, and H. Karatzias. 2010. Clinicopathological evaluation of downer dairy cows with fatty liver. Can. Vet. J. 51:615-622.

Kalaitzakis, E., N. Roubies, N. Panousis, K. Pourliotis, E. Kaldrymidou, and H. Karatzias. 2006. Evaluation of ornithine carbamoyl transferase and other serum and liver-derived analytes in diagnosis of fatty liver and postsurgical outcome of left-displaced abomasums in dairy cows. J. Am. Vet. Med. Assoc. 229:1463-1471.

Littell, R. C., G. A. Milliken, W. W. Stroup, R. D. Wolfinger, and O. Schabenberger. 2006. SAS for Mixed Models. 2nd ed. SAS Institute Inc., Cary, NC.
Mashek, D. G., K. L. Ingvartsen, J. B. Andersen, M. Vestergaard, and T. Larsen. 2001. Effects of a four-day hyperinsulinemic-euglycemic clamp in early and mid-lactation dairy cows on plasma concentrations of metabolites, hormones, and binding proteins. Domest. Anim. Endocrinol. 21:169-185.

McNamara, J. P., J. H. Harrison, R. L. Kincaid, and S. S. Waltner. 1995. Lipid metabolism in adipose tissue of cows fed high fat diets during lactation. J. Dairy Sci. 78:2782-2796.

Nielsen, N. I., N. C. Friggens, M. G. Chagunda, and K. L. Ingvartsen. 2005. Predicting risk of ketosis in dairy cows using in-line measurements of beta-hydroxybutyrate: A biological model. J. Dairy Sci. 88:2441-2453.

Palmquist, D. L., and T. C. Jenkins. 2003. Challenges with fats and fatty acid methods. J. Anim. Sci. 81:3250-3254.

Pantoja, J., J. L. Firkins, M. L. Eastridge, and B. L. Hull. 1994. Effects of fat saturation and source of fiber on site of nutrient digestion and milk production by lactating dairy cows. J. Dairy Sci. 77:2341-2356.

SAS Institute Inc. 1996. SAS Systems for Mixed Models. SAS Institute Inc., Cary, NC.

Schmitt, E., M. A. Ballou, M. N. Correa, E. J. DePeters, J. K. Drackley, and J. J. Loor. 2011. Dietary lipid during the transition period to manipulate subcutaneous adipose tissue peroxisome proliferator-activated receptor- $\gamma$ co-regulator and target gene expression. J. Dairy Sci. 94:5913-5925.

Sejersen, H., M. T. Sørensen, T. Larsen, E. Bendixen, and K. L. Ingvartsen. 2012. Liver protein expression in dairy cows with high liver triglycerides in early lactation. J. Dairy Sci. 95:2409-2421.

Sjaunja, L. O., L. Baevre, L. Junkkarinen, J. Pedersen, and J. Setälä. 1991. A Nordic proposal for an energy corrected milk (ECM) formula. Pages 156-157 in EAAP publication 50: Performance Recordings of Animals - State of the Art. P. Gaillon and Y. Chabert, ed. Centre for Agricultural Publishing and Documentation (PUDOC), Wageningen, the Netherlands.

Tennant, B. C. 1997. Liver function. Chapter 13 in Clinical Biochemistry of Domestic Animals. 5th ed. J. J. Kaneko, J. W. Harvey, and M. L. Bruss, ed. Academic Press, San Diego, CA.

Vandehaar, M. J., G. Yousif, B. K. Sharma, T. H. Herdt, R. S. Emery, M. S. Allen, and J. S. Liesman. 1999. Effect of energy and protein density of prepartumdiets on fat and protein metabolism of dairy cattle in the periparturient period. J. Dairy Sci. 82:1282-1295.

Weisbjerg, M. R., and C. F. Børsting. 1989. Influence of fat and feed level on fiber digestibility in vitro and in sacco and on volatile fatty acid proportions in the rumen. Acta Vet. Scand. Suppl. 86:137-139.

Winkelman, L. A., T. H. Elsasser, and C. K. Reynolds. 2008. Limitfeeding a high-energy diet to meet energy requirements in the dry period alters plasma metabolite concentrations but does not affect intake or milk production in early lactation. J. Dairy Sci. 91:1067-1079 